\title{
"The relationship between e-CRM and customer loyalty: a Kenyan Commercial Bank case study"
}

\begin{tabular}{|c|c|}
\hline \multirow{3}{*}{ AUTHORS } & Eric E. Mang'unyi iD https://orcid.org/0000-0002-5035-104X \\
\hline & Oumar T. Khabala \\
\hline & R http://www.researcherid.com/rid/U-1710-2017 \\
\hline ARTICLE INFO & $\begin{array}{l}\text { Eric E. Mang'unyi, Oumar T. Khabala and Krishna K. Govender (2017). The } \\
\text { relationship between e-CRM and customer loyalty: a Kenyan Commercial Bank } \\
\text { case study. Banks and Bank Systems, 12(2), 106-115. } \\
\text { doi:10.21511/bbs.12(2).2017.11 }\end{array}$ \\
\hline DOI & http://dx.doi.org/10.21511/bbs.12(2).2017.11 \\
\hline RELEASED ON & Tuesday, 11 July 2017 \\
\hline RECEIVED ON & Friday, 07 April 2017 \\
\hline \multirow[t]{2}{*}{ ACCEPTED ON } & Friday, 12 May 2017 \\
\hline & $((c))$ EY-NC \\
\hline LICENSE & $\begin{array}{l}\text { This work is licensed under a Creative Commons Attribution-NonCommercial } 4.0 \\
\text { International License }\end{array}$ \\
\hline JOURNAL & "Banks and Bank Systems" \\
\hline ISSN PRINT & $1816-7403$ \\
\hline ISSN ONLINE & $1991-7074$ \\
\hline PUBLISHER & LLC "Consulting Publishing Company "Business Perspectives" \\
\hline FOUNDER & LLC "Consulting Publishing Company "Business Perspectives" \\
\hline
\end{tabular}

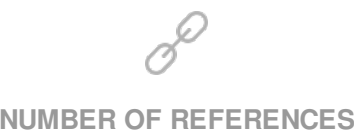

71

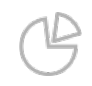

NUMBER OF FIGURES

3

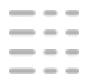

NUMBER OF TABLES

5

(C) The author(s) 2022. This publication is an open access article. 
Eric E. Mang'unyi (South Africa), Oumar T. Khabala (Kenya), Krishna K. Govender (South Africa)

\title{
The relationship between e-CRM and customer loyalty: a Kenyan Commercial Bank case study
}

\begin{abstract}
Since customer loyalty is key, especially in the highly competitive commercial banking environment, this article evaluated the effects of features of electronic customer relationship management (e-CRM) on customer loyalty. Using a crosssectional survey design, data were collected from a convenience sample of customers of a major international Kenyan bank using self-administered questionnaires. The findings based on correlation and multiple regression analyses, revealed that pre-service, during (the) service and post transactional e-CRM features have a positive and significant relationship with loyalty, and that the pre-service and during the service features significantly predict loyalty. Thus, enhancing e-CRM practices could be a strategic competitive tool to impact the banks' relationship with their customers.
\end{abstract}

Keywords: commercial banks, customer relations, electronic services, Kenya.

JEL Classification: O31, L81, L86.

Received on: $7^{\text {th }}$ of April, 2017.

Accepted on: $12^{\text {th }}$ of May, 2017.

\section{Introduction}

Customer relationship management (CRM) assists an institution to tap into a range of business benefits such as profitability, customer satisfaction, allegiance (Koçoglu and Kirmaci, 2012; Nguyen and Mutum, 2012; Peštek and Lalović, 2012) while enabling effective communication between the firm and the customer (Gikenye, 2011; Gikenye and Ocholla, 2014). CRM is vital to service quality and a quick response to market changes (Jamali, Moshabaki, Aramoon and Alimohammadi, 2013). Due to technological advances, the use of e-CRM as a marketing paradigm is increasing (Bahrami, Ghorbani and Arabzad, 2012; Thuo, Kibera, K'Obonyo and Wainaina, 2011), and it is used as a strategy to enhance organizational flexibility (Dubihlela and Khosa, 2014; Jamali et al., 2013; Jih, 2011; Salehi, Kheyrmand and Faraghian, 2015; Sigala, 2011).

E-CRM is defined as 'technology-centred' relationship marketing and ensuing advantages, incorporating traditional customer relationship management (CRM) tactics and e-business market place applications used by an organization to maintain customer relations (Dubihlela and Khosa, 2014; Harrigan, Ramsey and Ibbotson, 2012; Keshvari, 2012; KimSoon and Zulkifli, 2012; Salehi et al., 2015). Webbased technologies use the Internet to enable organizations to attract new customers, analyze their preferences and behaviors, customize support services while increasing services and value benefits, retain customers, and craft tactics to encourage loyalty

(c) Eric E. Mang'unyi, Oumar T. Khabala, Krishna K. Govender, 2017. Eric E. Mang'unyi, Walter Sisulu University, South Africa. Oumar T. Khabala, Jesuit Historical Institute in Africa, Kenya Krishna K. Govender, Prof., University of KwaZulu-Natal, Durban, South Africa.

This is an Open Access article, distributed under the terms of the Creative Commons Attribution-NonCommercial 4.0 International license, which permits re-use, distribution, and reproduction, provided the materials aren't used for commercial purposes and the original work is properly cited..
(Ata and Toker, 2012). In essence, e-CRM is used by staff at all levels of business to enable them to interact with customers electronically (Lam, Cheung and Lau, 2013; Tauni, Khan, Durrani and Aslam, 2014). The Internet and web technologies facilitate the implementation of e-CRM (Dolly and Pruthi, 2014; Küster, Vila and Canales, 2016), since they are web-based interaction platforms between the institution and their customers (Abdulfattah, 2012; Grover, 2011). Therefore, the features that make up e-CRM remain critical for managing customer relationships online, and building and maintaining loyalty. These features include concrete websites or Internet-based tools integrated into organizational systems, which, when properly customized, enable the required interaction with the customer (Grover, 2011). Thus, the relationship with the customer cannot be realized through the Internet without effective e-CRM, and, in order to succeed, relationship management, therefore, remains an initiative that requires commitment, a correct mindset, and an overarching strategic CRM ethos (Govender, 2004).

Some researchers (Ata and Toker, 2012; Azila and Noor, 2011; Salehi et al., 2015) have suggested that numerous business benefits accrue from the implementation of e-CRM, which enhances customer satisfaction and loyalty. In the light of the aforementioned, this paper explores how commercial banks may use technology and e-CRM to manage customer relationships and achieve customer loyalty.

\section{Literature review and research hypotheses}

1.1. The service relationship. There are three levels of a service experience, namely, pre-service, during the service sale and after service, which help fortify relationships while increasing overall customer satisfaction (Khalifa and Shen, 2009). According to the Transaction Cycle Framework (TCF) (Feinberg and Kadam, 2002), the three features in e-CRM, namely, pre-transaction, during transaction and post- 
transaction, are encountered by the customer during a service purchase, at the time of purchase, and after the purchase (Belch and Belch, 2010). The transaction cycle reinforces the three-stage relationships while increasing the overall customer satisfaction. The consumer's behavior with regard to a service enables a marketer to establish a products' or service's position, so as to increase its consumption (Belch and Belch, 2010), as well as appreciating buying processes (Siwach and Dahiy, 2009). Thus, it can be stated that e-CRM depends upon an understanding of consumer buying behavior (Grover, 2011, p. 37).

Pre-service transaction features include sign-in or log in capabilities, information customization and personalization, and information search capabilities, including several items, for example, site customization, local search engine and chat in the pre-purchase stage will lead to site traffic, pre-purchase satisfaction, trust and retention (Peštek and Lalović, 2012; Rozita, 2012; Tian and Wang, 2014). Personalization of communication while making it efficient between seller and buyer, as well as of a product or a service, will draw customers towards the firm (Lam, Cheung and Lau, 2013; Mogharabi, Akbarabadi, Mirnezhad and Kariznoee, 2014), since they get good experience (Nikhashemi, Paim and Haque, Khatibi and Tarofder, 2013; Wells, Valacich and Hess, 2011) and support their final purchase decisions (Zeithaml, Bitner and Gremler, 2012). According to Zeithaml et al. (2012), online information efficiency is referred to as eservice quality, since a customer who is satisfied with the e-service may purchase the product or service. The organization would, therefore, be able to get more information about the customer and package this information as per individual customer's needs and desires (Ha and Janda, 2014; Hung, Chen and Huang, 2014; Peng, Wang, He and Tang, 2015). Customized alerts as a pre-transaction feature can enable the customers to pre-specify and automatically receive information about new services, which the banks release (Tanveer, 2009).

Different e-CRM features during transaction stage can influence a customer's decision to complete the online transaction. Customers' education is vital at this point (Khalifa and Shen, 2009). The customers' education includes guidance provided on the procedures to purchase a service or product, criteria to consider, and how to evaluate them. It is at this stage that service suppliers and customers agree on the conditions of their transaction based on their negotiation, and, then, the transaction is completed. As such, security and privacy need to be considered to reduce any perceived risk and give clients sufficient confidence and a greater feeling of security in performing online transactions (Kim, Chung and Lee,
2011; Küster et al., 2016; Olupot and Kituyi, 2013; Rozita, 2012). Marketing tools such as emails, site personalization, loyalty schemes, price information, and reward schemes strengthen the relationship between a company and a customer (Yoon, Choi and Sohn, 2008). Online surveys assist in attitude judgment and possible evaluation of customer behavior significant for website customization (Park, Cho and Rao, 2012), as such, the organization is obliged to provide information pertaining purchase conditions.

Post-service e-CRM features comprises frequently asked questions (FAQs), problem solving and online feedback (Khalifa and Shen, 2009), which essentially entails customer service. Usually a help desk is established, where all customer correspondence issues with regard to a service or product are channeled thereby, creating a 'personal interaction' with the organization (Peštek and Lalović, 2012). New technological tools such as the Internet, wireless communications, speech recognition, and video help organizations are used to integrate all customer interactions on a central platform providing customers with more control on the services they want (Abdulfattah, 2012). Some researchers, for example, Olupot and Kituyi (2013) have stressed components such as FAQs, complaints ability feature, problem solving feature (online self-help functionality), feedback channels, order tracking and online communities. Since customer satisfaction is a postpurchase experience (Assouad and Overby, 2016), the aforementioned features are critical for increasing the customers' post-purchase satisfaction via one-to-one communication and support from the company's website. Therefore, e-service quality will be assessed based on the competence and enthusiasm of service providers to respond to the customer's problems after the purchase and, their willingness to inform customers about their special offers and complementary services or products (Park et al., 2012). Good e-service quality at the post e-CRM stage is believed to increase online customer's eloyalty (Alim and Ozuem, 2014; Koçoglu and Kirmaci, 2012; Lam et al., 2013).

1.2. E-CRM. Adoption of e-CRM has been a recent strategy in the majority of business organizations, more particularly the developing countries, and, as such, managers have strategically invested in on-line technologies while emphasizing the building and maintaining of worthy linkages with profitable customers (Harrigan et al., 2012; Nguyen and Mutum, 2012; Sigala, 2011; Thuo et al., 2011). Merging technology, processes and other business activities around the customer has facilitated CRM applications (Abdulfattah, 2012), enabling organizations to recognize the best customer, increase their satisfaction and loyalty (Alhaiou, 2011; Tian and Wang, 
2014). Effective use of relationship marketing can help to create competitive advantage (Harrigan et al., 2012; Karimi and Sarkhosh, 2006, p. 706; Thuo et al., 2011); and firms that have implemented fundamental e-CRM practices are reaping numerous benefits ranging from superior customer service, improved profitability, sales, reduced operational costs, enlarged customer base and a broader market share (Jamali et al., 2013; Kihara, 2015). The aforementioned benefits emanating from eCRM practices are associated with customer satisfaction (Alim and Ozuem, 2014; Rabbai, 2013). It is, therefore, vital to create more value to customers since this nurtures interpersonal ties that lead to repeat purchases that benefit the business and consumer marketing.

Recent studies (Abdulfattah, 2012; Rahimiparvar, 2014) on the use of e-CRM in building customer relationships established that it affects online customer satisfaction, service quality and retention (Khalifa and Shen, 2009; Tian and Wang, 2014), and promotes the development of an attractive virtual community which further enhance satisfaction (Alim and Ozuem, 2014). Researchers (Koçoglu and Kirmaci, 2012) have also identified e-CRM antecedents of loyalty in the financial services industry. Therefore, an organization's resources such as organization-customer interface, flexibility, speed of response, etc., need to be positively augmented in the relationship between e-CRM practices and marketing throughput.

1.3. E-CRM and customer loyalty. The advent of new technologies has led to a shift from CRM to eCRM, and with increasing global penetration of the internet, e-CRM has become a more popular communication tool and relationship-building platform (Lam et al., 2013). Organizations, therefore, are keen to deploy different types of e-CRM strategies to attract, maintain, and enhance customer relationships, which contribute to loyalty and the organization's success (Chess Media Group and Lieberman, 2010; Yun and Good, 2007). However, relationship management is an initiative that requires commitment, strategic CRM tenets and a correct mindset in order for it to succeed (Govender, 2004). Tanveer (2009) postulates that e-CRM infrastructure provides support to valuable customers to remain loyal, since information stored in the e-CRM database assists an organization to look at the actual cost of attracting and retaining customers. The firm can also access new international customers and seize valuable data essential to the firm's competitiveness and market share (Harrigan, Ramsey and Ibbotson, 2009). Azila and Noor (2011) assert that the association between e-CRM and customer loyalty means that the more customers are satisfied, they repur- chase and spread positive word-of-mouth about the service and the provider, which tends to result in longer relationships, trust in, and commitment to the service provider. As such, loyalty will continue to play crucial roles in the organization's competitiveness and profitability (Rahman, 2006). This is supported by some researchers (Gorondutse, Hilman and Nasidi, 2014; Hayes, 2008; Khan and Fasih, 2014; Olupot and Kituyi, 2013) who have suggested that e-CRM impacts on loyalty.

Alhaiou (2011) who studied the relationship between e-CRM features and e-loyalty on online shoppers at the different stages of transaction cycle argued that the use of e-CRM in building consumer relationships affects online consumer satisfaction and loyalty. A similar study by Abdulfattah (2012) investigated the effects of various e-CRM features at different stages of the transaction cycle, on customer satisfaction on banks' websites. The aforementioned researcher also established that e-CRM influences customer relationships and enhances online customer satisfaction and service quality. Rabbai (2013) confirmed the effect of e-CRM on customer loyalty, while Alim and Ozuem (2014) concluded that eCRM is effective in strengthening relationships with customers and promoting the development of an attractive virtual community, which further enhances satisfaction.

\section{Conceptual framework}

The literature revealed that the characteristics of three stages of a transaction cycle, namely, pre-transaction, during-transaction and post-transaction which constitute e-CRM (independent variable), impact on customer e-loyalty (dependent variable). The dependent variable (customer e-loyalty) is concerned with the purchase and user behavior, attitudes towards the bank and the purchasing or service consumption situation. Recent studies (Abdulfattah, 2012; Sivaraks, Kirairit and Tang, 2011) postulated that e-CRM features influence customer satisfaction, service quality and loyalty. In addition, Alim and Ozuem (2014) and also Peštek and Lalović (2012) reiterated that e-CRM characteristics are effective in reinforcing relationships with customers, and promoting the development of an attractive virtual community which significantly impacts satisfaction and loyalty. Tauni et al. (2014) postulated significant relationships between CRM and customer retention. Prior marketing research conducted in the financial services sector has shown that e-CRM features are antecedents of customer loyalty (Koçoglu and Kirmaci, 2012; Sivaraks et al., 2011).

Whereas the moderator variable in the e-CRM-eloyalty relationship is customer satisfaction, the mediating variable (includes factors such as Internet accessibility, network setup, perceived IT usage, 
previous experience with the bank, etc.) explains the relation between e-CRM and loyalty. This implies that it is not necessarily true that the existence of these transactional features of a bank's electronic platform could lead to loyalty, since other features may come into play to bridge the gap. An example would be the lack of Internet accessibility, which would limit a customer's use of the e-CRM features, and negative perceptions about ICTs would adversely impact its role in enhancing customer loyalty. Previous experience with the bank and/or its employees would also come into play depending on whether they were positive or negative. Therefore, to validate the effect of the e-CRM dimensions on customer e-loyalty, the findings of this study may shed light on the interrelationships among the variables, and help the banking industry to improve the quality of e-CRM activities, thus, enhancing customer loyalty. Figure 1 illustrates the conceptual model of the study, which will be empirically evaluated.

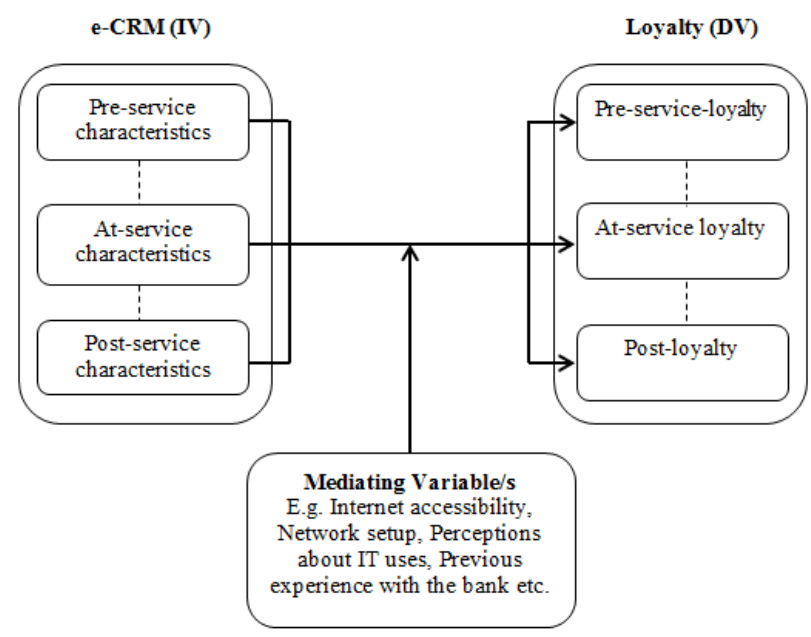

Fig. 1. Conceptual model

\section{Research methodology}

3.1. Research design. A quantitative approach using a cross-sectional survey design was implemented, because it is an appropriate strategy in establishing relationships between variables (Creswell, 2014). A bank-intercept survey was used to collect data.

\subsection{Population, sample and sampling proce-} dures. The research population consisted of all customers of the Standard Chartered Bank residing in the capital city of Kenya. The unit of analysis was all customers registered and using Internet technology-based applications provided by the bank to access their services. Since a complete list of all customers within the headquarters of the bank was not freely available to the researchers, numerous visits were made to the select branch to conduct the survey among the customers who were at the bank during that time and who met the criteria. The aforementioned bank's headquarters was selected for its convenience due to the difficulty of collecting data from other branches about their e-CRM performance. In addition, e-CRM had recently been relaunched by the bank, therefore, it was an opportunity to assess its performance from the customers' standpoint. One of the researchers is an employee of the bank, which made it easier to get permission to conduct the study. The sample was selected using convenience sampling method where a 'bankintercept survey' strategy was employed in order to gain a representative sample of the customers that constituted a percentage of the total population (Gorard, 2013). Convenience sampling designs, generally, have been embraced in service marketing and social science research (Etikan, Musa, Alkassim, 2016). Therefore, customers who visited the bank for services were invited to participate, and those who agreed to the request were provided with a questionnaire to complete. In addition, the statistical methods applied to test the hypotheses needed to be sufficient enough to perform the relevant statistical analyses.

This research comprised three predictor variables, and since it is suggested that for multiple regression analysis the desired level is between 15 and 20 observations for each variable (Hair, Black, Babin and Anderson, 2010), the researchers aimed at a sample size of not less than 60 . The questionnaires were distributed at 'opportunistic' bank locations such as in the ATM lobby and banking hall. A total of 78 customers were conveniently surveyed and included in the final sample and their responses werefit for analysis (Lin and Jones, 1997).

3.3. Data collection instrument. A selfadministered questionnaire was used to collect data from the bank's customers. The questionnaire required the respondents to supply background data, namely, their gender, age, level of education, years of dealing with the bank, duration of use of the bank's Internet/electronic-based services, and frequency of use of these services every month. Further sections consisted of questions measuring pre-, at-, and post-services e-CRM, and e-loyalty at each stage. The questions in the aforementioned sections comprised six items for each stage of e-CRM, developed on a five-point scale with $1=$ strongly disagree and $5=$ strongly agree. E-loyalty was also measured on a 5-point Likert scale where $1=$ not at all influential and $5=$ extremely influential.

3.4. Pilot study. Prior to primary data collection, a pilot study was conducted in August 2016 among ten participant customers (Saunders, Lewis and Thornhill, 2012; Zikmund and Babin, 2010) who were randomly selected from outside the final sample to assure internal consistency out of their responses of the final instrument (Sekaran and Bougie, 
2016). Consequently, Cronbach alphas ( $\alpha$ ) for study variables were as follows: pre-service features and during service features had 6 components and their alphas were .754 and .607 , respectively. Post-service features had 4 components $(\alpha=.741)$; pre-service loyalty (components $4, \alpha=.834$ ); during service loyalty (components $4, \alpha=.829$ ); and post-service loyalty (components $4, \alpha=.840$ ). The aforementioned reliability results demonstrate that the Cronbach coefficient alphas were acceptable, as suggested by Hair et al. (2010), implying that the measurement instruments were fairly reliable. The reliability analysis permitted us to proceed with the main study.

3.5. Ethical considerations. The study adhered to necessary ethical guidelines (Sekaran and Bougie, 2010, 2016) of information confidentiality and privacy of the participants that was solely the responsibility of the researcher. Informed consent was sought from respondents by disclosing the procedures of the survey and respondents were informed that participation was voluntary and that they were free to withdraw at any time without any consequences. Common ethical research requirements on anonymity, independent work, storage and plagiarism were also observed (Creswell, 2014, p. 92).

\section{Hypotheses}

In light of the literature review, this paper explores if and how commercial banks (in Kenya) may use eCRM practices as a marketing strategy and keep customers loyal by using one bank as a case study. Thus, to examine various relationships, it is hypothesized that:

H1: pre-service transaction features have no significant relationship with pre-service customer loyalty at the commercial banks;

$\mathrm{H} 2$ : there is no statistically significant influence of 'during service transaction' features on commercial bank customer loyalty;

H3: post-transaction service features have no significant relationship with post-service customer loyalty at the commercial bank.

\section{Findings}

Table 1 show that the majority $(53.3 \%)$ of the customers (respondents) were male and (30.7\%) were aged between 36 to 40 years. With regard to their education level, the vast majority $(60 \%)$ had a bachelor's degree and $(25.3 \%)$ had a master's degree, and the majority (45.3\%) had been with the bank for 6 to 10 years. Furthermore, $52.0 \%$ have been using the bank's electronic services between 1-3 years and often uses e-CRM services in a month.
Table 1. Bio data of the respondents

\begin{tabular}{|l|c|c|c|}
\hline \multicolumn{1}{|c|}{ Characteristics } & N & $\%$ & Cumulative \% \\
\hline Gender & & & \\
\hline Male & 40 & 53.3 & 53.3 \\
\hline Female & 35 & 46.7 & 100.0 \\
\hline & & & \\
\hline Age (years) & & & \\
\hline$\leq 25$ & 7 & 9.3 & 9.3 \\
\hline $26-30$ & 14 & 18.7 & 28.0 \\
\hline $31-35$ & 22 & 29.3 & 57.3 \\
\hline $36-40$ & 23 & 30.7 & 88.0 \\
\hline $41-45$ & 7 & 9.3 & 97.3 \\
\hline$\geq 46$ & 2 & 2.7 & 100.0 \\
\hline Highest education level & & & \\
\hline Masters & 19 & 25.3 & 25.3 \\
\hline Bachelors & 45 & 60.0 & 85.3 \\
\hline Diploma & 6 & 8.0 & 93.3 \\
\hline Certificate & 4 & 5.4 & 98.7 \\
\hline High school & 1 & 1.3 & 100.0 \\
\hline Duration & & & \\
\hline$<1$ year & 3 & 4.0 & 4.0 \\
\hline $1-5$ years & 20 & 26.7 & 30.7 \\
\hline $6-10$ years & 34 & 45.3 & 76.0 \\
\hline $11-15$ years & 12 & 16.0 & 92.0 \\
\hline $16-20$ years & 6 & 8.0 & 100.0 \\
\hline & & & \\
\hline & & & \\
\hline & & & \\
\hline & & & \\
\hline
\end{tabular}

Source: survey data 2017, SPSS output.

5.1. Diagnostic test results. Since simple linear and multiple regression analyses were conducted, the suitability of the data for the aforementioned procedures were investigated and the assumptions for multiple regression were considered. First, the measures, especially for the dependent variable (customer loyalty), were converted into a continuous scale, and Shapiro-Wilk's W test, which is recommended for small and medium samples (Garson, 2012), was used to test the normality of the data. Considering that the data is normal when the Shapiro-Wilk (W) $p>.05$, it is evident from Table 2 that all the variables had normally distributed data, since there were no statistical significant differences noted in any of the variables with their corresponding normal scores.

Table 2 . Tests of normality

\begin{tabular}{|l|c|c|c|c|c|c|}
\hline \multirow{2}{*}{ Variables } & \multicolumn{3}{|c|}{ Kolmogorov-Smirnova } & \multicolumn{3}{c|}{ Shapiro-Wilk } \\
\cline { 2 - 7 } & Statistic & df & Sig. & Statistic & df & Sig. \\
\hline Pre-service features & .087 & 74 & $.200^{*}$ & .978 & 74 & .233 \\
\hline During service features & .111 & 74 & .024 & .967 & 74 & .055 \\
\hline Post-service features & .113 & 74 & .021 & .944 & 74 & .053 \\
\hline Customer satisfaction with CRM & .083 & 74 & $250^{*}$ & .979 & 74 & .240 \\
\hline Overall customer loyalty & .083 & 74 & $.200^{*}$ & .969 & 74 & .068 \\
\hline
\end{tabular}

*. This is a lower bound of the true significance.

a. Lilliefors Significance Correction. 
Further, the tests of assumptions of multicollinearity performed using correlation (Table 3) reveal that all the correlation coefficients were less than 0.8 , implying that the population data were free of singularity, and that there was no multicollinearity. However, Huck (2010) recommends that inter-correlation among the independent variable beyond .08 is a sign of multi-collinearity and data should be subject to further scrutiny. Tolerance and the Variance Inflation Factor (VIF) tests were conducted to examine the existence of any violation of multi-collinearity assumptions. Table 4 shows that the collinearity conditions were met, given that each of the variables had adequate tolerance value $>$ .10 , and the VIF $<10$. The Durbin-Watson statistic of independence of observation was 1.893 , also implying that the data were not auto-correlated (Ayinde, Apata and Alaba, 2012).

Table 3. Correlation matrix of research variables

\begin{tabular}{|l|l|c|c|c|c|}
\hline \multicolumn{2}{|c|}{ Variables } & $\begin{array}{c}\text { Pre- } \\
\text { service } \\
\text { features }\end{array}$ & $\begin{array}{c}\text { During } \\
\text { service } \\
\text { features }\end{array}$ & $\begin{array}{c}\text { Post- } \\
\text { service } \\
\text { features }\end{array}$ & $\begin{array}{c}\text { Customer } \\
\text { satisfaction }\end{array}$ \\
\hline $\begin{array}{l}\text { Pre- } \\
\text { service } \\
\text { features }\end{array}$ & $\begin{array}{l}\text { Pearson correla- } \\
\text { tion }\end{array}$ & 1 & & & \\
\cline { 2 - 6 } & Sig. (2-tailed) & & & & \\
\cline { 2 - 6 } & $\mathrm{N}$ & 75 & & & \\
\hline \multirow{2}{*}{$\begin{array}{l}\text { During } \\
\text { service } \\
\text { features }\end{array}$} & $\begin{array}{l}\text { Pearson correla- } \\
\text { tion }\end{array}$ & $.643^{* *}$ & 1 & & \\
\cline { 2 - 6 } & Sig. (2-tailed) & .000 & & & \\
\cline { 2 - 6 } & $\mathrm{N}$ & 75 & 75 & & \\
\hline \multirow{2}{*}{$\begin{array}{l}\text { Post- } \\
\text { service } \\
\text { features }\end{array}$} & $\begin{array}{l}\text { Pearson correla- } \\
\text { tion }\end{array}$ & $.488^{* *}$ & $.567^{* *}$ & 1 & \\
\cline { 2 - 6 } & Sig. (2-tailed) & .000 & .000 & & \\
\cline { 2 - 6 } & $\mathrm{N}$ & 75 & 75 & 75 & \\
\hline $\begin{array}{l}\text { Customer } \\
\text { satisfaction } \\
\text { with CRM }\end{array}$ & $\begin{array}{l}\text { Pearson correla- } \\
\text { tion }\end{array}$ & $.310^{* *}$ & $.356^{* *}$ & $.309^{* *}$ & 1 \\
\cline { 2 - 6 } & Sig. (2-tailed) & .007 & .002 & .007 & \\
\cline { 2 - 6 } & $\mathrm{N}$ & 75 & 75 & 75 & 75 \\
\hline **. Correlation is significant at the 0.01 level (2-tailed). & \\
\hline
\end{tabular}

Table 4. Tolerance and Variance Inflation Factor (VIF) statistics

\begin{tabular}{|l|c|c|}
\hline \multirow{2}{*}{\multicolumn{1}{|c|}{ Model }} & \multicolumn{2}{c|}{ Collinearity statistics } \\
\cline { 2 - 3 } & Tolerance & VIF \\
\hline (Constant) & & \\
\hline Pre-service features & .560 & 1.785 \\
\hline During service features & .490 & 2.040 \\
\hline Post-service features & .643 & 1.555 \\
\hline Customer satisfaction with CRM & .850 & 1.177 \\
\hline
\end{tabular}

5.2. Influence of pre-service transaction features on customer loyalty. The Pearson's product moment test showed a moderate positive correlation between the pre-service e-CRM features and customer loyalty $(r=.531, p<.05)$, with an increase in the pre-service e-CRM features associated to an increase customer loyalty and vice versa. Since the aforementioned results did not support hypothesis 1 , it was concluded that pre-service e-CRM features have a significant influence on customer loyalty. This finding supports that of previous researchers, interalia, Rozita (2012), Wells et al. (2011) and Zeithaml et al. (2012). Figure 2 further supports this relationship, since the scatter plot diagram pattern indicates positive correlation between the variables, and the line of best fit further reveals that there was correlation between the variables. Regression estimates and the Analysis of Variance (ANOVA) of the level of influence of pre-service e-CRM features on customer loyalty showed that the pre-service eCRM features were a significant predictor of customer loyalty $\left[\mathrm{F}(1,73)=28.6, \mathrm{p}<.001, \mathrm{R}^{2}=.282\right]$.

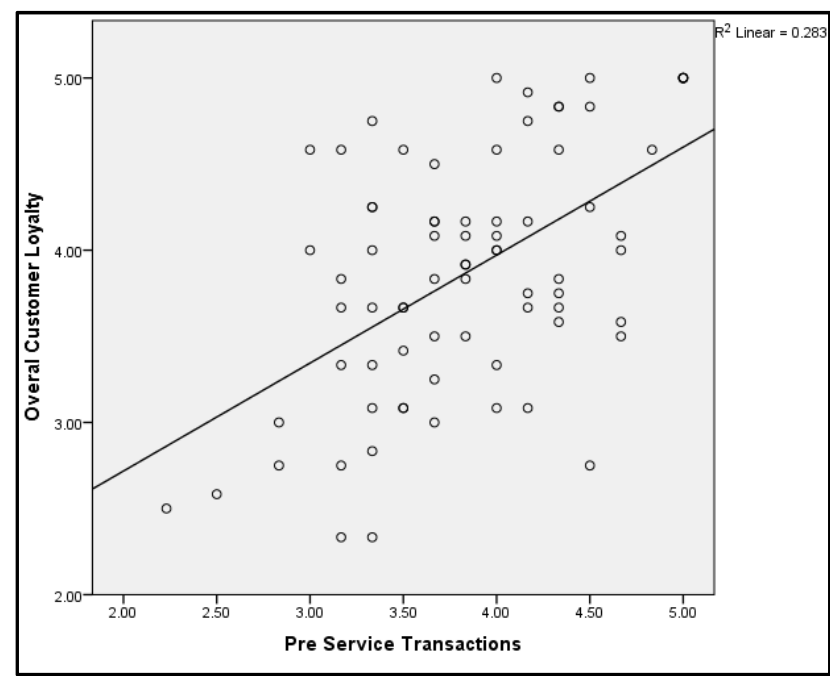

Fig. 2. Scatter plot: pre-service e-CRM and customer loyalty

5.3. Influence of during (the) service e-CRM features on customer loyalty. Figure 3 reveals that the during (the) service e-CRM features have a significant positive relationship with customer loyalty $[r$ $=.556 ; p<0.05]$, therefore, hypothesis 2 is rejected. The results support that the proposition that during (the) service e-CRM is an antecedent to loyalty, with high levels of during (the) service e-CRM features associated with enhanced customer loyalty at the commercial banks (Yoon, Choi and Sohn, 2008). The calculated coefficient of determination showed that the during (the) service e-CRM features were a significant predictor of customer loyalty to the bank $\left[\mathrm{F}(1,73)=32.721, p<.001, \mathrm{R}^{2}=.310\right]$, and accounted for much of the variability in loyalty among the bank customers.

5.4. Influence of post service e-CRM features on customer loyalty. A statistically significant $[\mathrm{r}=$ $.398, p<.05]$ correlation exists between the postservice e-CRM and customer loyalty; thus, hypothesis 3 is rejected. It is also evident that the postservice e-CRM feature is a significant predicator of customer loyalty $[\mathrm{F}(1,73)=13.701, p<.05]$. Several researchers, interalia, Alim and Ozuem (2014), Koçoglu and Kirmaci (2012) and Lam et al. (2013), also supported the positive impact of post-services e-CRM features on customer loyalty. 


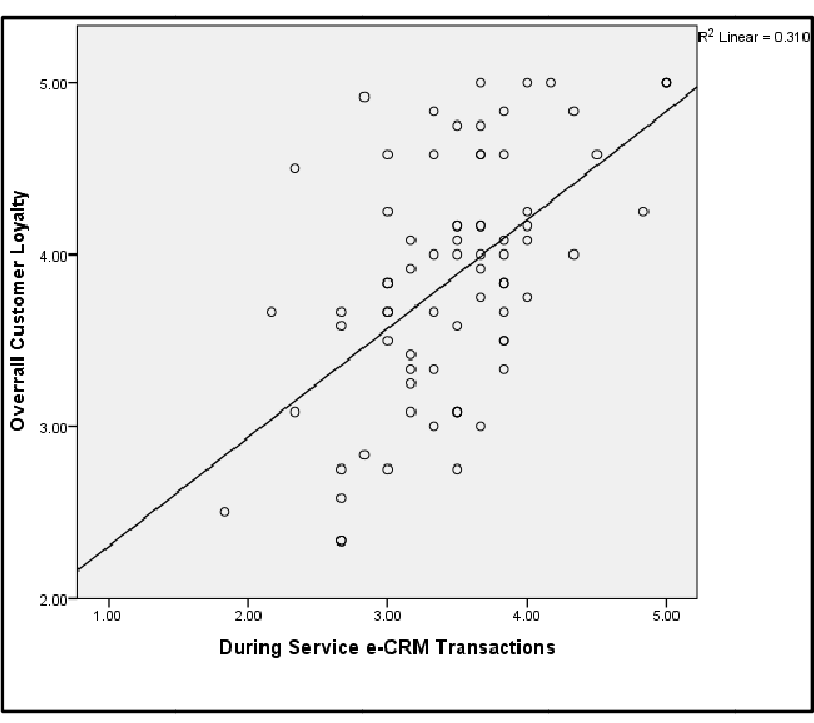

Fig. 3. Scatter plot graph: during service e-CRM and customer loyalty

5.5. Multiple regression results. By using standard multiple regression analysis, all three independent variables (pre-service, during (the) service, and postservice e-CRM features were included in the model at once to evaluate each independent variable's predictive power (Hair et al., 2010). To compare the different variables, a standardized coefficient was used (Table 5). From Table 5, it is evident that the three levels of service transaction e-CRM contributed differently to influencing the overall customer loyalty. For example, during the service e-CRM features had the highest impact on enhancing customer loyalty (beta $=.345 \mathrm{p}=.011$ ), while the post eCRM features made the least contribution to explaining the variability of the model. Therefore, "during (the) service e-CRM" made the strongest unique contribution to explaining the dependent variable. This means that a one standard deviation increase in "during service e-CRM" transaction feature leads to a .345 standard deviation increase in predicted customer loyalty, with the other variables held constant. With beta $=.055$, a one standard deviation increase in post service e-CRM would only lead to a 0.055 standard deviation increase in customer loyalty, however, this effect was not significant $(p=.647)$. It was, therefore, not surprising to discover that, despite the fact all the other two variables made a statistically significant $(p<.05)$, unique contribution to the equation, only the post service e-CRM variable did not indicate any statistical significance. Hence, it was concluded that the post service e-CRM variable did not make a significant contribution to the prediction of customer loyalty.

Table 5. Coefficient outputs: e-CRM and customer loyalty

\begin{tabular}{|c|c|c|c|c|c|c|c|c|c|c|}
\hline \multirow{2}{*}{ Model } & \multicolumn{2}{|c|}{ Unstandardized coefficients } & \multirow{2}{*}{$\begin{array}{c}\text { Standardized coefficients } \\
\text { Beta }\end{array}$} & \multirow{2}{*}{$\mathrm{T}$} & \multirow{2}{*}{ Sig. } & \multicolumn{2}{|c|}{$95.0 \%$ confidence interval for B } & \multicolumn{3}{|c|}{ Correlations } \\
\hline & B & Std. error & & & & Lower bound & Upper bound & Zero-order & Partial & Part \\
\hline (Constant) & 1.017 & .470 & & 2.166 & .034 & .081 & 1.953 & & & \\
\hline Pre-service e-CRM & .334 & .151 & .282 & 2.211 & .030 & .033 & .634 & .531 & .254 & .209 \\
\hline During service e-CRM & .393 & .150 & .345 & 2.619 & .011 & .094 & .692 & .556 & .297 & .248 \\
\hline Post-service e-CRM & .052 & .114 & .055 & .460 & .647 & -.175 & .280 & .398 & .055 & .044 \\
\hline
\end{tabular}

a. Dependent variable: overall customer loyalty.

5.5.1. The regression model. A regression model for the relationship between the independent variables (pre-service e-CRM features, during-service e-CRM features, post-service e-CRM features), and the dependent variable of the study, therefore, is

$Y=\beta_{\mathrm{o}}+\beta_{1} x_{1}+\beta_{2} x_{2}+\beta_{3} x_{3}+\varepsilon$,

where $\mathrm{Y}$ is overall customer loyalty among the customers of the bank; $X_{1}$ - pre-service e-CRM features; $X_{2}$ - during service e-CRM features; $X_{3}$ - post service e-CRM features.

The optimum level of overall customer loyalty to the bank is presented by 1.017 units $+.334 x_{1}$ units + $+.393 x_{2}$ units $+.052 x_{3}$ units + error term .

The above equation indicates how much the customer loyalty varies with an increase and/or a change in the independent variable, when all other independent variables are held constant. For example, the unstandardized coefficient $\left(\mathrm{X}_{1}\right)$ for the pre-service eCRM is equal to .334 , implying that with one unit increase in the pre-service e-CRM, there is an in- crease in customer loyalty by .334 units. Similarly, for each unit increase in the during service e-CRM features, there is an increase in customer loyalty by .393 units. However, for a unit increase in the postservice e-CRM features, there is only .052 unit increase in customer loyalty. We conclude that the model was adequate to predict customer loyalty in the bank, since it was statistically significant [F (3, $\left.71)=13.507, p<.05, \mathrm{R}^{2}=.363\right]$. More than a third $(36.3 \%)$, of the variability in the customer loyalty in the bank is explained by the independent variables factored in the model, implying that other factors (not included in this regression model) could account for about $64 \%$ of the model.

\section{Conclusion, recommendations and future research}

The results support the basic theoretical propositions about relationship management and customer loyalty. This study shows there is a positive and significant correlation between e-CRM and loyalty, and the pre-service and during service features of a 
transaction significantly influence customer loyalty. The result clearly supports the proposition that the eCRM construct is an antecedent to loyalty. Another interesting finding is that although post-service e-CRM is positively related to loyalty, it is not a significant predictor of customer loyalty $(p>0.05)$. Therefore, it is concluded that customer loyalty in the commercial bank is largely dependent on the pre-service and during service transactional features. In theory, this implies that the e-CRM features are important criterion for a customer of the bank to complete a transaction, hence this increases their loyalty.

The findings have also revealed that e-CRM is positively related to customer loyalty, which is significantly influenced by the pre-service and during service features, but not by the post-service features. This advances our understanding of the influence of e-CRM on loyalty for example, enhancing marketing strategy in general. It is concluded that future investigation of the relationship between the two constructs should take into account moderating factors like customer satisfaction, age, gender etc. that may have an effect on the relationship.

This study was limited in terms of the sampling, since a convenience sample was used. The positive yet non-significant effect of the post-service features on loyalty needs to be examined further. The potential exists to replicate the study with a larger sample of the participants employing mixed methods and more sophisticated analysis techniques such as structural equation modeling (SEM).

\section{References}

1. Abdulfattah, F. H. (2012). The effect of electronic customer relationship on customer satisfaction a study on web banking in Saudi Arabia. Unpublished PhD Thesis, University of Huddersfield, West Yorkshire, England. Retrieved 12 June 2016 from http://eprints.hud.ac.uk/id/eprint/18098/

2. Alhaiou, T. A. (2011). A Study on the Relationship between e-CRM Features and E-Loyalty: the case in UK. Unpublished PhD thesis, Brunel Business School, Brunel University, West London. Retrieved 24 April 2016 from http://www.core.ac.uk/download/pdf/1440953.pdf

3. Alim, S., and Ozuem, W. (2014). The influences of e-CRM on customer satisfaction and loyalty in the UK mobile industry. Journal of Applied Business and Finance Researches, 3(2), 47-54.

4. Assouad, A., and Overby, J. (2016). The impact of culture on customer expectations. Journal of Management Policy and Practice, 17(2), 19-32.

5. Ata, U. Z., and Toker, A. (2012). The effect of customer relationship management adoption in business-tobusiness markets. Journal of Business \& Industrial Marketing, 27(6), 497-507.

6. Ayinde, K., Apata, E. O., and Alaba, O. O. (2012). Estimators of linear regression model and prediction under some assumptions violation. Open Journal of Statistics, 2(5), 534-546. http://dx.doi.org/10.4236/ojs2012.25069

7. Azila, N., and Noor, M. (2011). Electronic customer relationship management performance: its impact on loyalty from customers' perspectives. International Journal of e-Education, e-Business, e-Management and e-Learning, 1(1), 1-6.

8. Bahrami, M., Ghorbani, M., and Arabzad, S. M. (2012). Information technology (IT) as an improvement tool for customer relationship management (CRM). Procedia - Social and Behavioral Sciences, 41, 59-64. http://dx.doi.org/10.1016/j.sbspro.2012.04.008

9. Belch, G. E., and Belch, M. A. (2010). Advertising and promotion (7th ed.). New York: Tata McGraw-Hill.

10. Chess Media Group, and Lieberman, M. (2010). Guide to understanding social CRM. Chess Media Group. Retrieved 28 March, 2017 from http://www.sales20conf.com/SF2012/PDFs/Guide_to_Understanding_Social_CRM.pdf

11. Creswell, J. W. (2014). Research design: Qualitative, quantitative and mixed methods approaches. Thousand Oaks, CA: Sage Publications, Inc.

12. Dolly, and Pruthi, A. (2014). E-CRM framework: Service to customer perspective. International Journal of Advanced Research in Computer Science and Software Engineering, 4(4), 1363-1366.

13. Dubihlela, J., and Khosa, P. M. (2014). Impact of e-CRM implementation on customer loyalty, customer retention and customer profitability for hoteliers along the Vaal Meander of South Africa. Mediterranean Journal of Social Sciences, 5(16), 175-183. http://dx.doi.org/10.5901/mjss.2014.v5n16p175

14. Feinberg, R. A., Kadam, R., Kokama, L., and Kim, I. (2002). The state of electronic customer relationship management in retailing. Journal of International Retail and Distribution Management, 30(10), 470-481.

15. Feinberg, R., and Kadam, R. (2002). E -CRM web service attributes as determinants of customer satisfaction with retail websites. International Journal of Service Industry Management, 13(5), 432-451.

16. Garson, G. D. (2012). Testing statistical assumptions. North Carolina State University School of Public and International Affairs, Statistical Associates Publishing.

17. Gikenye, W. (2011). The diffusion of mobile phones for business and information management in Kenya. Proceedings of the European Conference on Information Management, 511-520. Retrieved from http://connection.ebscohost.com/c/articles/78120473/diffusion-mobile-phones-business-information-management-kenya

18. Gikenye, W., and Ocholla, D. N. (2014). The diffusion of information and communication technologies in the informal sector in Kenya. Mousaion, 32(3), 29-48.

19. Gorard, S. (2013). Research design: Robust approaches for marketing. London: University of Wisconsin.

20. Gorondutse, A. H., Hilman, H., and Nasidi, M. (2014). Relationship between Corporate Reputation and customer loyalty on Nigerian food and beverages industry: PLS approach. International Journal of Management Business Research, 4(2), 125-136. 
21. Govender, C. (2004). Customer relationship management as a model for growth in banks. Unpublished MBA thesis, University of KwaZulu-Natal. Retrieved 4 August 2016 from http://hdl.handle.net/10413/2280

22. Grover, D. (2011). Effective customer relationship management through e-CRM. Viewpoint, 2(1), 27-38.

23. Ha, H. Y., and Janda, S. (2014). The effect of customized information on online purchase intentions. Internet Research, 24(4), 496-519.

24. Hair, J. F., Black, W. C., Babin, B. J., and Anderson, R. E. (2010). Multivariate data analysis: A global perspective. New York: Pearson Prentice Hall.

25. Harrigan, P., Ramsey, E., and Ibbotson, P. (2008). e-CRM in SMEs: An exploratory study in Northern Ireland. Marketing Intelligence and Planning, 26(4), 385-404.

26. Harrigan, P., Ramsey, E., and Ibbotson, P. (2009). Investigating the e-CRM activities of Irish SMEs. Journal of Small Business and Enterprise Development, 16(3), 443-465.

27. Harrigan, P., Ramsey, E., and Ibbotson, P. (2012). Entrepreneurial marketing in SMEs: the key capabilities of eCRM. Journal of Research in Marketing and Entrepreneurship, 14(1), 40-64.

28. Hayes, B. E. (2008). The true test of loyalty. Quality Progress, 41(6), 20-26.

29. Huck, S. J. (2010). Reading statistics and research (3rd ed.). New York: Longman.

30. Hung, S.Y., Chen, C. C., and Huang, N. H. (2014). An integrative approach to understanding customer satisfaction with e-service of online stores. Journal of Electronic Commerce Research, 15(1), 40-57.

31. Jamali, R., Moshabaki, A., Aramoon, H., and Alimohammadi, A. (2013). Customer relationship management in electronic environment. The Electronic Library, 31(1), 119-130. http://dx.doi.org/10.1108/02640471311299173

32. Jih, W. J. (2011). Impact of e-CRM on website loyalty of a public organization's customers. Information Resources Management Journal, 24(2), 46-60.

33. Karimi, F., and Sarkhosh, R. (2006). A conceptual framework for electronic customer relationship management (eCRM): a strategic approach. In Emerging Trends and Challenges in Information Technology Management, 706708. Hershey: Idea Group Publishing.

34. Keshvari, R. S. (2012). The impact of E-CRM on customers attitude and its association with generating competitive advantages in Iranian financial B2B context. International Business Research, 5(4), 34-54. http://dx.doi.org/10.5539/ibr.v5n4p34

35. Khalifa, M., and Shen, N. (2009). Modeling electronic customer relationship management success: functional and temporal considerations. Journal of Behaviour and Information Technology, 28(4), 373-387.

36. Khan, M. M., and Fasih, M. (2014). Impact of service quality on customer satisfaction and customer loyalty: evidence from banking sector. Pakistan Journal of Commerce and Social Sciences, 8(2), 331-354.

37. Kihara, S. N. (2015). The effect of mobile banking on the competitive advantage of commercial banks in Kenya. Unpublished MBA thesis, United States International university-Africa. Retrieved 5 April 2016 from http://erepo.usiu.ac.ke/handle/11732/685

38. Kim, M. J., Chung, N., and Lee, C. K. (2011). The effect of perceived trust on electronic commerce: shopping online for tourism products and services in South Korea. Tourism Management, 32, $256-265$. http://dx.doi.org/10.1016/j.tourman.2010.01.011

39. Kim-Soon, N., and Zulkifli, M. F. (2012). The impact of electronic customer relationship management (e-CRM) on the business performance of small company. Journal of Engineering and Technology, 3(12), 139-153.

40. Koçoglu, D., and Kirmaci, S. (2012). Customer relationship management and customer loyalty; a survey in the sector of banking. International Journal of Business and Social Science, 3(3), 282-291.

41. Küster, I., Vila, N., and Canales, P. (2016). How does the online service level influence consumers' purchase intentions before a transaction? A formative approach. European Journal of Management and Business Economics, 25, 111-120.

42. Lam, A. Y. C., Cheung, R., and Lau, M. (2013). The influence of internet-based customer relationship management on customer loyalty. Contemporary Management Research, 9(4), 419-440. http://dx.doi.org/10.7903/cmr.11095

43. Lin, B., and Jones, C. A. (1997). Some issues in conducting customer satisfaction surveys. Journal of Marketing Practice: Applied Marketing Science, 3(1), 4-13.

44. Mogharabi, V., Akbarabadi, L., Mirnezhad, R., and Kariznoee, A. (2014). Examining the role of electronic customer relationship management (E-CRM) on attracting customers in internet marketing. Interdisciplinary Journal of Contemporary Research in Business, 5(10), 252-260.

45. Nguyen, B., and Mutum, D. (2012). A review of customer relationship management: successes, advance, pitfalls and futures. Journal of Business Process Management, 18(3), 2-4.

46. Nikhashemi, S. R., Paim, L.,Haque, A., Khatibi, A., and Tarofder, A. K. (2013). Internet technology, CRM and customer loyalty: customer retention and satisfaction perspective. Middle-East Journal of Scientific Research, 14(1), 79-92.

47. Olupot, C., and Kituyi, G. M. (2013). A framework for the adoption of electronic customer relationship management information systems in developing countries. The Electronic Journal in Electronic Systems in Developing Countries, 58(3), 1-19.

48. Park, I., Cho, J., and Rao, H. R. (2012). The effect of pre- and post-service performance on consumer evaluation of online retailers. Decision Support Systems, 52(2), 415-426.

49. Peng, Z., Wang, J., He, K., and Tang, M. (2015). Web service customization based on service feature model. In 2015 IEEE International Conference on Services Computing, 632-639. New Yok, NY: The Institute of Electrical and Electronics Engineers. http://dx.doi.org/10.1109/SCC.2015.91 
50. Peštek, A., and Lalović, A. (2012). Challenges of electronic customer relationship management (e-CRM) in rent-acar sector in Bosnia and Herzegovina. Economic Research-Ekonomska Istraživanja, 25(2), $103-116$. http://dx.doi.org/10.1080/1331677X.2012.11517576

51. Rabbai, R. A. (2013). Investigating the impact of e-CRM on customer loyalty: a case of B2B in Zain company in Jordan. Unpublished Master in E-Business thesis, Business Administration Faculty, Middle East University, Jordan. Retrieved 5 May 2016 from https://meu.edu.jo/uploads/1/58749ce6546b1_1.pdf

52. Rahimiparvar, N. (2014). eCRM features that affect customer attitude to loyalty: a case study of university students enrolled in international programs in Thailand. GSBE Journal, 36-51. Retrieved 28 March 2017 from www.graduate.au.edu/gsbejournal/Journals/Dec2014/Journal03.pdf

53. Rahman, Z. (2006). Customer experience management: A case study of an Indian bank. Journal of Database Marketing and Customer Strategy Management, 13(3), 203-221.

54. Rozita, S . K. (2012). The impact of E-CRM on customer attitude and its association with generating competitive advantages in Iranian financial B2B context. Journal of International Business Research, 5(4), 12-18.

55. Salehi, S., Kheyrmand, M., and Faraghian, H. (2015). Evaluation of the effects of e-CRM on customer loyalty (Case Study: Esfahan branches of Sepah Bank). Paper presented at the 9th International Conference on e-commerce with focus on e-business on 16th April, 2015, Isfahan, Iran, 1-8. Retrieved from http://www.ecdcconference.org

56. Saunders, M., Lewis, P., and Thornhill, A. (2012). Research methods for business students (6th ed.). Harlow: Pearson.

57. Sekaran, U., and Bougie, R. (2010). Research methods for business: A skill building approach (5th ed.). New York: John Wiley and Sons, Inc.

58. Sekaran, U., and Bougie, R. J. (2016). Research methods for business: A skill building approach (7th ed.). West Sussex: John Wiley and Sons Ltd.

59. Sigala, M. (2011). eCRM 2.0 applications and trends: The use and perceptions of Greek tourism firms of social networks and intelligence. Computers in Human Behavior, 27(2), 655-661.

60. Sivaraks, P., Kirairit, D., and Tang, J. C. S. (2011). Effects of e-CRM on customer - bank relationship quality and outcomes: The case of Thailand. Journal of High Technology Management Research, 22, 141-157.

61. Siwach, M., and Dahiy, A. S. (2009). Knowledge and utilization of consumer education by rural and urban women. Journal of Human Ecology, 25(1), 41-44.

62. Tanveer, A. (2009). Electronic customer relationship management in online banking. Unpublished Master's thesis, Luleå University of Technology, Sweden. Retrieved 24 April 2016 from www.divaportal.org/smash/get/diva2:1018049/FULLTEXT01.pdf

63. Tauni, S., Khan, R., Durrani, M., and Aslam, S. (2014). Impact of customer relationship management on customer retention in the telecom industry of Pakistan. Industrial Engineering Letters, 4(10), 54-59.

64. Thuo, J. K., Kibera, F. N., K'Obonyo, P. P., and Wainaina, G. (2011). Customer relationship management and competitiveness of commercial banks in Kenya. Journal of Science Technology Education and Management, 4(1), 125-141.

65. Tian, S., and Wang, S. (2014). Signaling service quality via website eCRM features: more gains from smaller or lesser known hotels. Journal of Hospitality and Tourism Research, 1-35. http://dx.doi.org/10.1177/1096348014525634

66. Wang, M. (2008). Measuring e-CRM service quality in the library context: a preliminary study. The Electronic Library, 26(6), 896-911.

67. Wells, J. D., Valacich, J. S., and Hess, T. J. (2011). What signal are you sending? How website quality influences perceptions of product quality and purchase intentions. MIS Quarterly, 35, 373-396.

68. Yoon, D., Choi, S. M., and Sohn, D. (2008). Building customer relationships in an electronic age: the role of interactivity of e-commerce web sites. Journal of Psychology and Marketing, 25(7), 602-618.

69. Yun, Z., and Good, L. K. (2007). Developing customer loyalty from e-tail store image attributes. Managing Service Quality: An International Journal, 17(1), 4-22.

70. Zeithaml, V., Bitner, M. J., and Gremler, D. (2012). Services marketing: Integrating customer focus across the firm (6th ed.). India: McGraw-Hill.

71. Zikmund, W., and Babin, B. (2010). Exploring marketing research (10th ed.). South Western: Cengage Learning. 